\title{
Population genetic analysis of Caiman crocodilus (Linnaeus, 1758) from South America
}

\author{
William R. Vasconcelos ${ }^{1}$, Tomas Hrbek ${ }^{1,2}$, Ronis Da Silveira ${ }^{3}$, Benoit de Thoisy ${ }^{4}$, Boris Marioni ${ }^{5}$ \\ and Izeni P. Farias ${ }^{1}$ \\ ${ }^{1}$ Universidade Federal do Amazonas, Departamento de Ciências Biológicas, Laboratório de Evolução \\ e Genética Animal, Mini Campus ICB, Manaus, AM, Brazil. \\ ${ }^{2}$ University of Puerto Rico, Biology Department, San Juan, Puerto Rico. \\ ${ }^{3}$ Universidade Federal do Amazonas, Departamento de Ciências Biológicas, Laboratório de Zoologia, \\ Mini Campus ICB, Manaus, AM, Brazil. \\ ${ }^{4}$ Association Kwata, Cayenne, French Guiana. \\ ${ }^{5}$ Instituto Piagaçu-Purus, Manaus, AM, Brazil.
}

\begin{abstract}
The genetic structure of Caiman crocodilus was investigated using a $1085 \mathrm{bp}$ mtDNA fragment of the cytochrome $b$ gene. Inferences were based on 125 individuals from nine localities in Peru, Brazil and French Guiana. With the exception of Mamirauá Lake, Anavilhanas Archipelago and the Tapará Community which show a signal of demographic expansion, the sampled localities are in a mutation-drift genetic equilibrium. Divergence between the Amazon basin and extra-Amazon basin localities is significant; however, inference from Nested Clade Analysis cannot distinguish between continuous range expansion, long distance colonization or past fragmentation; however, past fragmentation is unlikely due to low number of mutational steps separating these two regions. The divergence is probably maintained by the reduced ability of $C$. crocodilus to cross salt water barriers. Within the Amazon basin, continuous range expansion without isolation-by-distance is the most likely process causing genetic structuring. The observed genetic patterns are compatible with the ecology of $C$. crocodilus, and history of human exploitation. As commercial hunting depleted more valuable species, $C$. crocodilus expanded its range and ecological niche, prompting hunters to harvest it. Following a period of intense hunting, $C$. crocodilus is now experiencing recovery and a second population expansion especially in protected areas.
\end{abstract}

Key words: genetic structure, phylogeography, genetic diversity, demographic expansion, cytochrome $b$, Caiman crocodilus.

Received: April 13, 2005; Accepted: October 24, 2005.

\section{Introduction}

The study of spatial and temporal distribution of intraspecific genetic variability is one of the principal foci of molecular ecology. They provide important data that shed light on evolutionary processes and spatio-temporal dynamics of often complex natural populations of the Neotropics. It is these evolutionary processes that allow species to adapt to dynamically changing environments that should be conserved (Smith et al., 1997; Smith et al., 2001). Therefore, molecular ecological studies can provide vital information for the conservation and management of biological diversity.

Send correspondence to Izeni Pires Farias. Universidade Federal do Amazonas, Departamento de Ciências Biológicas, Laboratório de Evolução e Genética Animal, Mini Campus ICB, Av. Gen. Rodrigo Octávio Jordão Ramos 3000, 69077-000 Manaus, AM, Brazil. E-mail: izeni_farias@ufam.edu.br.
Brazil, and in particular Amazônia, is rich in biodiversity (Myers et al., 2000). Of the seven alligatorid crocodilians (family Alligatoridae), five to six species occur in Brazil and four to five of those occur in Amazônia. The Brazilian species are classified in the genera Caiman, Melanosuchus and Paleosuchus. Melanosuchus is restricted to the Amazon, Essequibo and Oiapoque basins, while Paleosuchus is also found in the Orinoco basin and coastal drainages of The Guianas and the littoral of Brazil. Caiman has a much wider distribution, and is found from southern Mexico to northern Argentina, including all major South American drainages. Caiman crocodilus (the spectacled caiman) can reach $2.5 \mathrm{~m}$ of total body length. Females reach sexual maturity at three to four years of age (Staton and Dixon, 1977), the same age as Alligator mississipiensis, which is much less than the average age of 
nine years at female sexual maturity found in other crocodilian species (Brisbin Jr., 1988).

The taxonomy of Caiman is not firmly established, but most recent taxonomic studies recognize the species $C$. crocodilus, C. yacare and C. latirostris (Busack and Pandya, 2001). Caiman latirostris is found in the Paraná and São Francisco River basins, and C. yacare maily occurs in the Pantanal and Bolivian basins but also extends along the Madeira River into the Amazon basin. Caiman crocodilus is the most widely distributed species, found from southern Mexico south to the Amazon River basin (Ross, 1998). Caiman crocodilus has been classified into three subspecies in addition to the nominal subspecies. However, the only analysis that investigated morphological differentiation among regions of occurrence, and thus the validity of these subspecies, failed to show any consistent differences among the subspecies, rejecting their validity (Busack and Pandya, 2001). Caiman yacare, which sometimes is included as a subspecies of C. crocodilus, was significantly differentiated from C. crocodilus at a series of morphological and morphometric traits (Busack and Pandya, 2001).

Populations of C. crocodilus became severely threatened by the hide trade between 1960 and 1969, when more than 1.5 million skins were exported legally from the Brazilian Amazon (Smith, 1980). Harvest started focusing on C. crocodilus when commercially more desirable species, such as Melanosuchus niger, became too severely depleted to be harvested profitably. A little more than two decades thereafter, in studies conducted between 1993 and 1996 in the Jaú National Park, Rebêlo and Lugli (2001) found little demographic evidence of past overexploitation. The authors attributed the apparent well being of $C$. crocodilus in this area to a demographic recovery from past overexploitation. A pattern of demographic recovery is also observed in other regions of Amazônia (George Rebêlo personal communication).

Little is known about population genetic structuring and gene-flow patterns of $C$. crocodilus. Up to now, the only population genetic study is that of Farias et al. (2004) which investigated $C$. crocodilus from two localities in Brazil (Piagaçu-Purus Reserve and Janauacá Lake) and one locality in French Guiana (Approuague River). The authors found a signal of population expansion and high levels of genetic polymorphism in all three populations. They also found significant genetic differentiation between French Guiana and Brazil. However, the sampling scheme of Farias et al. (2004) was inadequate to discriminate among alternative historical processes underlying the observed differentiation between French Guiana and Brazil. It was also unable to test the hypothesis of panmixia within the Amazon basin.

The objective of this study was to quantify genetic variability and its spatial distribution in $C$. crocodilus. We used these patterns to test two specific hypotheses: 1) have C. crocodilus populations experienced a demographic and genetic recovery, as hypothesized by Rebêlo and Lugli (2001) and Farias et al. (2004); and 2) does C. crocodilus of the Amazon basin form a panmictic population, as alluded to in Farias et al. (2004) and observed in other large Amazonian vertebrates (Cantanhede et al., 2005; Hrbek et al., 2005).

\section{Materials and Methods}

\section{Samples}

Samples of caudal scutes were collected from 125 individuals at nine localities during the years 2002, 2003 and 2004. The nine localities were: Approuague River (Kaw Swamps N.R.) in French Guiana; Uaçá River (A.I. Uaçá) in Amapá State, Brazil; São Miguel Island and the Tapará Community in Pará State, Brazil; the Anavilhanas Archipelago (E.E. Anavilhanas), Janauacá Lake, lower Purus River (Piagaçu-Purus RDS) and Mamirauá Lake (Mamirauá RDS) in Amazonas State, Brazil; and Pacaya-Samíria National Reserve in Peru (Figure 1). The majority of the samples was collected at night, and samples were preserved in $95 \%$ ethanol at ambient temperature until being processed in the laboratory.

\section{Laboratory protocol}

Total genomic DNA was extracted using a standard phenol/chloroform method and precipitated with $70 \%$ ethanol (Sambrook et al., 1989). The mitochondrial cytochrome

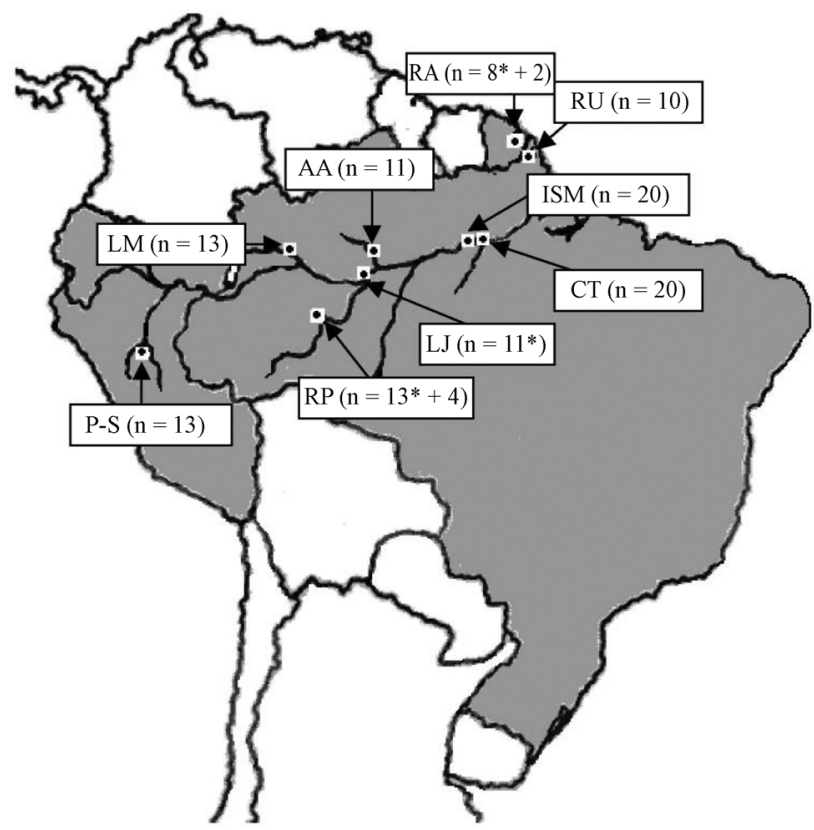

Figure 1 - Geographic distribution of the nine localities analyzed in this study. N corresponds to the number of individuals sampled. Sampled localities and their geographic coordinates are: Approuague River - AR

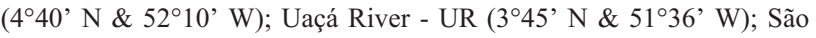
Miguel Island - SMI $\left(0^{\circ} 77^{\prime} \mathrm{S} \& 97^{\circ} 65^{\prime} \mathrm{W}\right)$; Tapará Community - TC $\left(0^{\circ} 77^{\prime} \mathrm{S} \& 97^{\circ} 65^{\prime} \mathrm{W}\right)$; Anavilhanas Archipelago - AA (2॰32' S \& 60 $15^{\prime}$ W); Janauacá Lake - JL ( $\left.3^{\circ} 26^{\prime} \mathrm{S} \& 60^{\circ} 17^{\prime} \mathrm{W}\right)$; Purus River - PR (44' $\mathrm{S}$

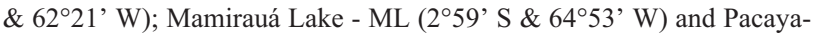
Samíria - P-S $\left(4^{\circ} 19^{\prime} \mathrm{S} \& 76^{\circ} 55^{\circ} \mathrm{W}\right)$. 
$b$ gene was amplified via Polymerase Chain Reaction (PCR) using the primers L14254 (5'-ATGACCCACCAACTACG AAAAT-3') from Glenn et al. (2002) and H15982 (5'-TCC CTRGCTTTGGTAGCCAGG-3') from Farias et al. (2004).

PCR reactions were carried out in a final volume of $25 \mu \mathrm{L}$ and contained $11.7 \mu \mathrm{L}$ of $\mathrm{ddH}_{2} \mathrm{O}, 3 \mu \mathrm{L}$ of $\mathrm{MgCl}_{2}$ (25mM), $2.5 \mu \mathrm{L}$ of dNTPs $(10 \mathrm{mM}), 2.5 \mu \mathrm{L}$ of $10 \mathrm{x}$ buffer $(100 \mathrm{mM}$ Tris- $\mathrm{HCl}, 500 \mathrm{mM} \mathrm{KCl}), 2 \mu \mathrm{L}$ of each primer $(2 \mu \mathrm{M}), 0.3 \mu \mathrm{L}$ of Taq DNA Polymerase $(5 \mathrm{U} / \mu \mathrm{L})$ and $1 \mu \mathrm{L}$ of DNA (concentration varied between $50 \mathrm{ng}$ and $100 \mathrm{ng}$ ). PCR conditions were as follows: denaturation at $92{ }^{\circ} \mathrm{C}$ for $35 \mathrm{~s}$, primer annealing at $55^{\circ} \mathrm{C}$ for $35 \mathrm{~s}$, and primer extension at $72{ }^{\circ} \mathrm{C}$ for $90 \mathrm{~s}$; these three steps were repeated 35 times, and followed by a final extension at $72{ }^{\circ} \mathrm{C}$ for 5 min. Purification of products was done using the GFXTM PCR DNA Kit (Amersham Bioscience, São Paulo) following the manufacturer's protocol.

Purified PCR products were sequenced directly. Each reaction contained $4 \mu \mathrm{L}$ of amplified DNA product ( $30 \mathrm{ng}$ ), $2 \mu \mathrm{L}$ of primer (L14254 for the 5' segment of the amplified DNA fragment, and L14731 (5'-TCGTGCCAT GAATTTGAG-3') from Glenn et al. (2002) as an internal primer for the 3 ' portion of our DNA fragment), $2 \mu \mathrm{L}$ of $5 \mathrm{x}$ replacement buffer $(400 \mathrm{mM}$ Tris- $\mathrm{HCl} \mathrm{pH} 9.0,10 \mathrm{mM}$ $\mathrm{MgCl}_{2}$ ) and $2 \mu \mathrm{L}$ of DYEnamic ET Dye Terminator mix (Amersham Bioscience, São Paulo). Cycle sequencing PCR conditions were as follows: denaturation at $93{ }^{\circ} \mathrm{C}$ for $15 \mathrm{~s}$, primer annealing at $50^{\circ} \mathrm{C}$ for $35 \mathrm{~s}$, and primer extension at $60{ }^{\circ} \mathrm{C}$ for $120 \mathrm{~s}$; these three steps were repeated 35 times. Resulting fluorescently labeled product was precipitated using a mixture of $70 \%$ ethanol and $175 \mathrm{mM}$ ammonium acetate. Precipitated DNA product was resuspended in Hi-Di Formamide, and resolved on a MegaBACE 1000 automatic DNA analysis system (Amersham Bioscience, São Paulo) using the manufacturer's recommended settings.

\section{Data verification}

Identity of the 125 DNA products was verified by comparing the data with cytochrome $b$ sequences of Alligator mississippiensis (AF318548-AF318557) (Glenn et al., 2002), Melanosuchus niger and Caiman crocodilus (AY462456-AY462487) (Farias et al., 2004), and C. crocodilus (NC002744) (Janke et al., 2001) deposited in GenBank. Sequences were aligned by eye in the program BioEdit (Hall, 1999), and conceptually translated into amino acids. The 1085 bp alignment did not show insertions or deletions, and translation produced no unexpected stop codons.

\section{Intraspecific analytical methods}

Relative contributions of historical and ongoing processes are not easy to distinguish, thus various strategies have been proposed (Templeton et al., 1987; Bernatchez, 2001). In this study we used the Nested Clade Analysis (NCA) developed by Templeton and colleagues (Templeton and Sing, 1993; Templeton et al., 1995; Templeton, 2001; 2004). The program TCS 1.18 (Clement et al., 2000) was used for haplotype network estimation following the cladogram estimation rules laid out in Templeton et al. (1992) and elaborated in Templeton (1998; 2004). The program Geodis 2.0 (Posada et al., 2000) was used to test significant changes in haplotype and nested clade geographic distribution relative to other haplotypes and nested clades within their higher-level nesting clades (Templeton et al., 1995). The program PAUP* $4.0 \mathrm{~b} 10$ (Swofford, 2002) was used to estimate a Neighbor Joining tree based on $F_{S T}$ values.

The number of segregating sites between sequences (S), Nei's (1987) nucleotide diversity ( $\pi$ ), Nei's (1987) gene diversity $(\hat{\mathrm{H}})$, and Watterson's $(1975)$ theta $(\theta)$ were calculated using the programs Arlequin ver. 2000 (Schneider et al., 2000) and DnaSP (Rozas et al., 2003). These programs were also used to compute pair-wise $F_{S T}$ statistics (Weir and Cockerham, 1984), Analysis of Molecular Variance (AMOVA) (Excoffier et al., 1992), and tests of selective neutrality of $\mathrm{Fu}$ (1997) and Tajima (1989). Fu's $F s$ is in general more powerful than the test of Tajima in detecting demographic events.

Wright's inbreeding coefficient $(F)$, the classic population genetic measure, was used to characterize intrapopulational variation and differentiation between populations. We used the method of Cockerham and Weir (1993) to estimate $F_{S T}$. Statistical significance of $F$ values was estimated using bootstrapping implemented in Arlequin 2000 (Schneider et al., 2000), and adjusted using the method of Bonferroni for multiple comparison (Rice, 1989). We tested the hypothesis of isolation by distance using the Mantel test (Mantel, 1967) implemented in the program Arlequin ver. 2000 (Schneider et al., 2000), estimating the significance of correlation between matrix of $\ln F_{S T}$ values and between-locality river distances with 10000 permutations.

Analysis of Molecular Variance (AMOVA) (Excoffier et al., 1992) tests if molecular variation is non-randomly distributed among user-defined or natural groups. In this study we used AMOVA to test two hypotheses: 1) that samples from the Amazon basin do not have a significantly different genetic composition from samples originating in the non-Amazonian Atlantic Ocean drainage systems, and 2) that sampling localities from the Amazon basin are not genetically differentiated from each other. Both test the null hypothesis of panmixia, however, at different hierarchical levels. Inferences from AMOVA were confirmed by Raymond and Rousset's test of exact population differentiation (Raymond and Rousset, 1995). 


\section{Results}

We sequenced 1085 base pairs (bp) of the mitochondrial cytochrome $b$ gene in 125 individuals sampled from nine localities (Figure 1). We found a total of 38 haplotypes (Tables 1 and 2) that included one common haplotype; this haplotype (H1) is the most frequent one and is widely distributed, two characteristics that are representative of a most likely ancestral haplotype (Castelloe and Templeton, 1994). The conceptual translation of the $1085 \mathrm{bp}$ fragment in the program BioEdit (Hall, 1999) resulted in a sequence of 361 amino acids without unexpected stop codons, con-

Table 1 - Variable sites in the 1085 bp fragment of the mitochondrial cytochrome $b$ gene of Caiman crocodilus. A total of 41 sites were variable resulting in 38 haplotypes. $\mathrm{N}$ indicates the number of individuals in which a particular haplotype was found. Haplotypes are deposited in GenBank under accessions numbers DQ246626 to DQ246663.

\begin{tabular}{|c|c|c|}
\hline Haplotype & Position of a nucleotide change & $\mathrm{N}$ \\
\hline & $\begin{array}{l}00000000000000000000000000000000000000111 \\
00000112222233445555566666777888889999000 \\
01367263444659791467801269129033571347115 \\
33201748039682849020408546193103205612473\end{array}$ & \\
\hline $\mathrm{H} 1$ & ACTGTCGAAGGCACGCGACCCATTTCATGCATCCCTTCCCC & 63 \\
\hline $\mathrm{H} 2$ & $\ldots \ldots \ldots \ldots \ldots \ldots \ldots \ldots \ldots \ldots \ldots \ldots$ & 1 \\
\hline H3 & $\ldots \ldots \ldots \ldots \ldots \ldots \ldots \ldots \ldots \ldots \ldots$ & 1 \\
\hline $\mathrm{H} 4$ & $\ldots \ldots \ldots \ldots \ldots \ldots \ldots \ldots \ldots \ldots \ldots$ & 1 \\
\hline H5 & $\ldots \ldots \ldots \ldots \ldots \ldots \ldots \ldots \ldots \ldots$ & 1 \\
\hline H6 & $\ldots \ldots \ldots \ldots$ T. $\ldots \ldots \ldots \ldots \ldots \ldots \ldots$ & 1 \\
\hline $\mathrm{H} 7$ & $\ldots \ldots \ldots \ldots \ldots \ldots \ldots \ldots \ldots \ldots \ldots \ldots$ & 1 \\
\hline $\mathrm{H} 8$ & 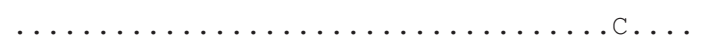 & 1 \\
\hline H9 & 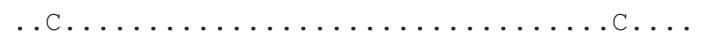 & 3 \\
\hline $\mathrm{H} 10$ & $\ldots \ldots \ldots \ldots \ldots \ldots$ т. $\ldots \ldots \ldots \ldots$ с. & 1 \\
\hline H11 & 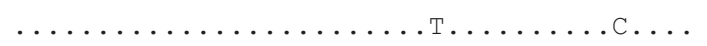 & 2 \\
\hline H12 & 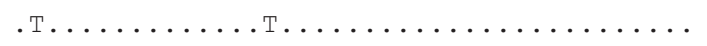 & 1 \\
\hline H13 &  & 1 \\
\hline H14 & 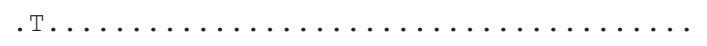 & 1 \\
\hline H15 & 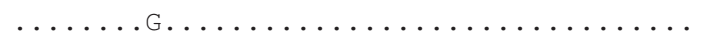 & 9 \\
\hline H16 & .т.т. т. & 1 \\
\hline $\mathrm{H} 17$ & 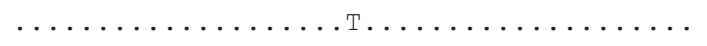 & 1 \\
\hline $\mathrm{H} 18$ & 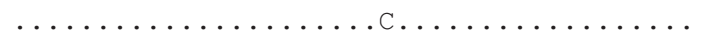 & 1 \\
\hline H19 & 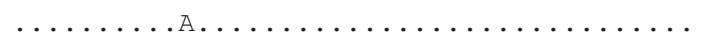 & 1 \\
\hline $\mathrm{H} 20$ & 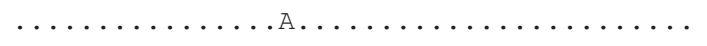 & 1 \\
\hline $\mathrm{H} 21$ & 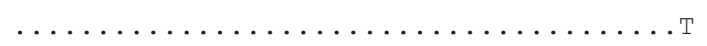 & 2 \\
\hline $\mathrm{H} 22$ & $\ldots \ldots$ А. & 1 \\
\hline $\mathrm{H} 23$ & 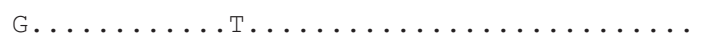 & 13 \\
\hline $\mathrm{H} 24$ & 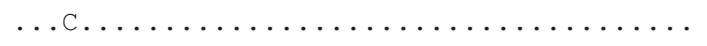 & 1 \\
\hline $\mathrm{H} 25$ & 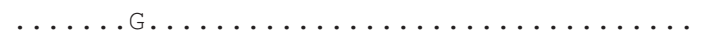 & 1 \\
\hline $\mathrm{H} 26$ & $\ldots$. $\ldots \ldots \ldots \ldots \ldots \ldots \ldots \ldots \ldots \ldots \ldots$ & 1 \\
\hline $\mathrm{H} 27$ & 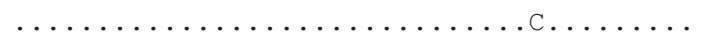 & 2 \\
\hline $\mathrm{H} 28$ & $\ldots \ldots \ldots \ldots \ldots \ldots \ldots \ldots \ldots \ldots \ldots \ldots$ с $\ldots$ & 1 \\
\hline $\mathrm{H} 29$ & $\ldots \ldots \ldots \ldots \ldots \ldots \ldots \ldots \ldots \ldots$ ттт.с... & 1 \\
\hline $\mathrm{H} 30$ & 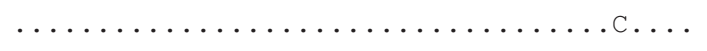 & 1 \\
\hline $\mathrm{H} 31$ & 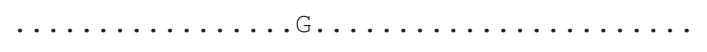 & 1 \\
\hline $\mathrm{H} 32$ & $\ldots \ldots \ldots \ldots \ldots \ldots \ldots \ldots \ldots$ T. & 1 \\
\hline H33 & $\ldots \ldots \ldots \ldots \ldots \ldots \ldots \ldots \ldots \ldots \ldots$ & 1 \\
\hline $\mathrm{H} 34$ & 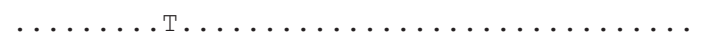 & 1 \\
\hline H35 & 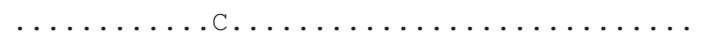 & 1 \\
\hline $\mathrm{H} 36$ &  & 1 \\
\hline $\mathrm{H} 37$ & 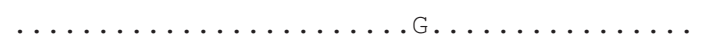 & 1 \\
\hline $\mathrm{H} 38$ & 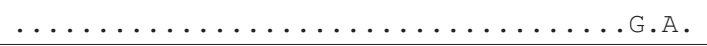 & 1 \\
\hline
\end{tabular}


firming that we have not amplified and sequenced nuclear pseudogenes. We also found an incomplete stop codon at the end of cytochrome $b$ characteristic of crocodilians (Glenn et al., 2002). A characteristic mtDNA anti-G bias (Zhang and Hewitt, 1996) was observed in all sequences. Haplotypes are deposited in GenBank under the accession numbers DQ246626 to DQ246663.

In the NCA (Templeton et al., 1995) we encountered two levels at which we could not reject the null hypothesis of no association of geographic distance and distribution of genetic diversity. Nesting scheme and significant levels are shown in Figure 2. Using the 14 July 2004 NCA interpretational key (see http://darwin.uvigo.es/software/geodis. $\mathrm{html}$ ), we inferred continuous range expansion, long distance colonization or past fragmentation in nesting level 3-1 (Table 3). This inference pertains to the contrast between sampling localities from the Amazon basin and those outside the Amazon basin. For localities from within the Amazon basin we infer continuous range expansion at level 2-2 (Table 3).

Table 2 - Haplotype frequencies of the mitochondrial cytochrome $b$ gene in sampling localities of C. crocodilus.

\begin{tabular}{|c|c|c|c|c|c|c|c|c|c|c|}
\hline \multirow{2}{*}{$\begin{array}{l}\text { Haplo- } \\
\text { types }\end{array}$} & \multicolumn{7}{|c|}{ Brazil } & \multirow{2}{*}{$\begin{array}{c}\text { Peru } \\
\text { Pacaya- } \\
\text { Samíria }\end{array}$} & \multirow{2}{*}{$\begin{array}{c}\text { French Guiana } \\
\text { Approuague } \\
\text { River }\end{array}$} & \multirow[t]{2}{*}{ Total } \\
\hline & Purus River & $\begin{array}{c}\text { Janauacá } \\
\text { Lake }\end{array}$ & $\begin{array}{l}\text { Anavilhanas } \\
\text { Archipelago }\end{array}$ & $\begin{array}{l}\text { Mamirauá } \\
\text { Lake }\end{array}$ & $\begin{array}{c}\text { Tapará } \\
\text { Community }\end{array}$ & $\begin{array}{l}\text { São Miguel } \\
\text { Island }\end{array}$ & Uaçá River & & & \\
\hline $\mathrm{H} 1$ & 15 & 5 & 4 & 3 & 18 & 12 & - & 6 & - & 63 \\
\hline $\mathrm{H} 2$ & - & - & - & - & - & - & - & 1 & - & 1 \\
\hline $\mathrm{H} 3$ & - & - & - & - & - & - & - & 1 & - & 1 \\
\hline $\mathrm{H} 4$ & - & - & - & - & - & 1 & - & - & - & 1 \\
\hline H5 & - & - & - & - & 1 & - & - & - & - & 1 \\
\hline H6 & - & - & - & 1 & - & - & - & - & - & 1 \\
\hline $\mathrm{H} 7$ & - & - & - & - & - & - & 1 & - & - & 1 \\
\hline $\mathrm{H} 8$ & - & - & - & - & - & - & 1 & - & - & 1 \\
\hline H9 & - & - & - & - & - & - & 3 & - & - & 3 \\
\hline $\mathrm{H} 10$ & - & - & - & 1 & - & - & - & - & - & 1 \\
\hline H11 & - & - & - & 2 & - & - & - & - & - & 2 \\
\hline H12 & - & - & 1 & - & - & - & - & - & - & 1 \\
\hline H13 & - & - & 1 & - & - & - & - & - & - & 1 \\
\hline H14 & - & - & 1 & - & - & - & - & - & - & 1 \\
\hline H15 & - & - & - & - & - & - & 3 & - & 6 & 9 \\
\hline H16 & - & - & - & - & - & - & 1 & - & - & 1 \\
\hline H17 & - & - & - & - & - & - & - & - & 1 & 1 \\
\hline H18 & - & - & - & - & - & - & - & - & 1 & 1 \\
\hline H19 & - & - & - & - & - & - & 1 & - & - & 1 \\
\hline $\mathrm{H} 20$ & - & 1 & - & - & - & - & - & - & - & 1 \\
\hline $\mathrm{H} 21$ & - & 2 & - & - & - & - & - & - & - & 2 \\
\hline $\mathrm{H} 22$ & - & 1 & - & - & - & - & - & - & - & 1 \\
\hline $\mathrm{H} 23$ & 1 & 1 & - & 1 & - & 5 & - & 5 & - & 13 \\
\hline $\mathrm{H} 24$ & - & - & - & 1 & - & - & - & - & - & 1 \\
\hline $\mathrm{H} 25$ & 1 & - & - & - & - & - & - & - & - & 1 \\
\hline $\mathrm{H} 26$ & - & 1 & - & - & - & - & - & - & - & 1 \\
\hline $\mathrm{H} 27$ & - & - & 2 & - & - & - & - & - & - & 2 \\
\hline $\mathrm{H} 28$ & - & - & 1 & - & - & - & - & - & - & 1 \\
\hline $\mathrm{H} 29$ & - & - & 1 & - & - & - & - & - & - & 1 \\
\hline H30 & - & - & - & 1 & - & - & - & - & - & 1 \\
\hline H31 & - & - & - & 1 & - & - & - & - & - & 1 \\
\hline H32 & - & - & - & 1 & - & - & - & - & - & 1 \\
\hline H33 & - & - & - & 1 & - & - & - & - & - & 1 \\
\hline H34 & - & - & - & - & 1 & - & - & - & - & 1 \\
\hline H35 & - & - & - & - & 1 & - & - & - & - & 1 \\
\hline H36 & - & - & - & - & - & 1 & - & - & - & 1 \\
\hline H37 & - & - & - & - & - & 1 & - & - & - & 1 \\
\hline $\mathrm{H} 38$ & - & - & - & - & - & - & - & - & 1 & 1 \\
\hline Total & 17 & 11 & 11 & 13 & 21 & 20 & 10 & 13 & 9 & 125 \\
\hline
\end{tabular}




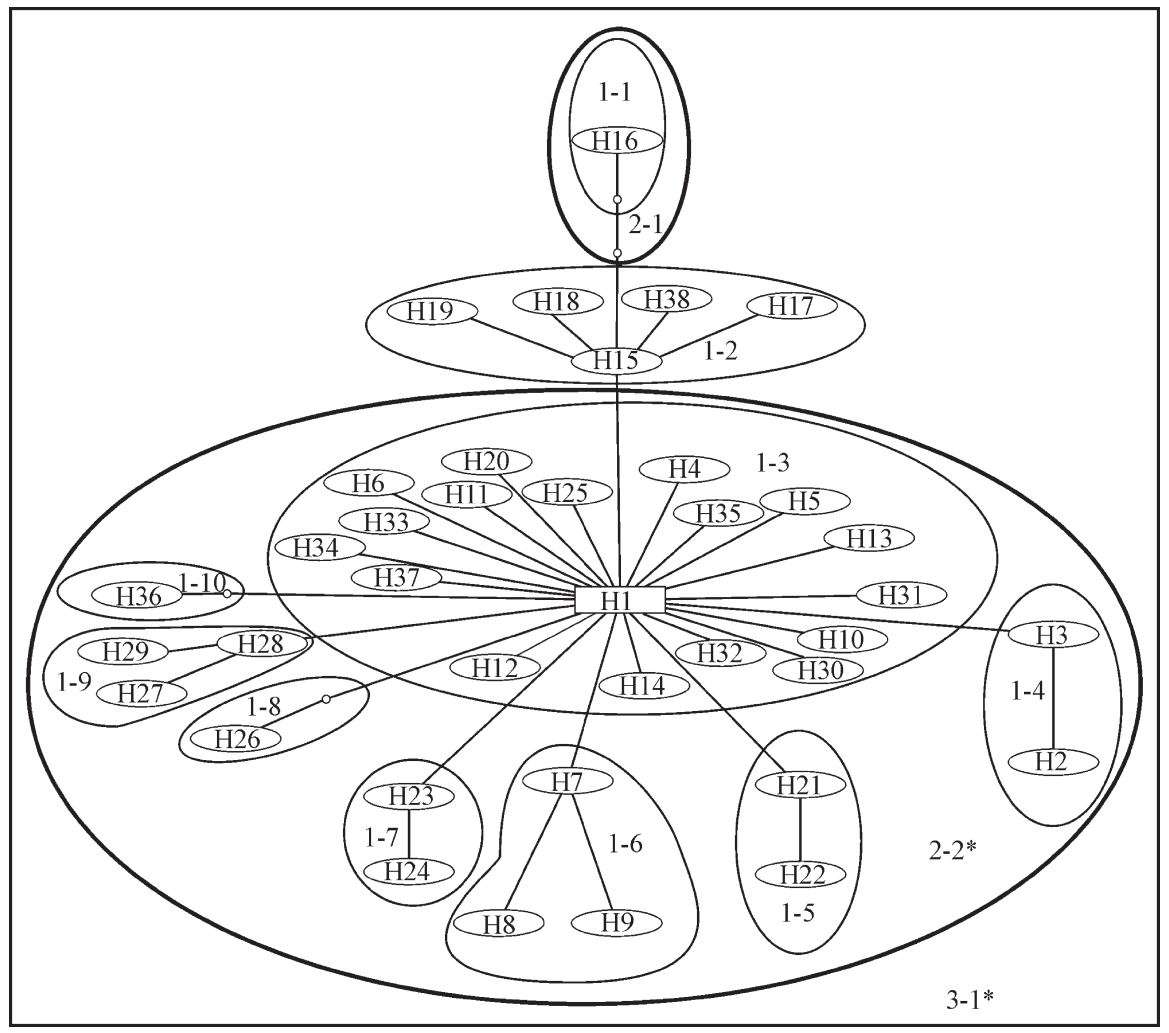

Figure 2 - Most parsimonious network of $38 \mathrm{mtDNA}$ haplotypes detected in the sample of 125 individuals of C. crocodilus. Lines represent one mutational step, circles represent haplotypes. The one square represents the most likely ancestral haplotype. Empty circles represent inferred, but not detected haplotypes. * indicates a significant nesting level inferred in NCA.

Table 3 - Results of Nested Clade Analysis (NCA) of C. crocodilus. Level refers to the nesting clades shown in Figure 2. Only those nesting clades that show genetic or geographic variation are reported. Permutational $\chi^{2}$ probability is assessed by randomly permuting the lower level clade categories within the nesting clade versus geographical locality 10000 times. Inferences are based on the 14 July 2004 key provided on the GeoDis 2.0 website (http://darwin.uvigo.es/software/geodis.html). $\mathrm{H}_{0}=$ no association of haplotypes with geography.

\begin{tabular}{lrrl}
\hline Level & \multicolumn{1}{c}{$\chi^{2}$} & Prob & Interpretation \\
\hline $1-2$ & 3.6111 & 0.7111 & $\mathrm{H}_{\mathrm{O}}$ not rejected \\
$1-3$ & 118.9418 & 0.0458 & $\begin{array}{l}\mathrm{H}_{\mathrm{O}} \text { not rejected (no significant nes- } \\
\text { ted contrasts within this nesting cla- } \\
\text { de) }\end{array}$ \\
$1-7$ & 6.4615 & 0.2845 & $\mathrm{H}_{\mathrm{O}}$ not rejected \\
$2-2$ & 229.5434 & 0.0000 & continuous range expansion \\
$3-1$ & 111.6078 & 0.0000 & $\begin{array}{l}\text { continuous range expansion, long } \\
\text { distance colonization or past frag- } \\
\text { mentation }\end{array}$ \\
\hline
\end{tabular}

Hierarchical AMOVA analysis (Excoffier et al., 1992) implemented in the program Arlequin ver. 2000 (Schneider et al., 2000) was used to investigate differentiation between the sampling localities of the Amazon basin and those of the Atlantic coast drainages. Results show that $35.30 \%$ of variation occurs between the two groups, $6.97 \%$ occurs among localities within the two groups, and $57.73 \%$ occurs within sampling localities. The genetic difference between the Amazon basin and the Atlantic coast drainages is significant $\left(F_{C T}=0.3530, \mathrm{p}=0.023\right)$, and is graphically illustrated in Figure 3.

A second AMOVA analysis concentrated exclusively on the Amazon basin. When the Amazon basin was treated as one group, $8.39 \%$ of the observed genetic variation occurred between localities, and $91.61 \%$ within localities. However, among locality differentiation is significant $\left(F_{S T}=0.0839, \mathrm{p}<0.001\right)$. Global test of exact population differentiation (Raymond and Rousset, 1995) also supported the hypothesis of differentiation among localities $(\mathrm{p}<0.001)$. We tested if this differentiation may be due to isolation-by-distance by testing for significant association of geographic distance and genetic divergence of sampled localities using the permutational procedure of Mantel (1967). Results of the Mantel test indicate that isolationby-distance is not a significant structuring factor, neither for all populations analyzed $(\mathrm{r}=0.4621, \mathrm{p}=0.058)$, nor for the Amazon basin only $(r=0.1036, p=0.354)$. Estimates of the gene flow parameter $\mathrm{Nm}$ derived from $F_{S T}$ values indicate that high levels of genetic exchange exist between nearly all sampled localities (Table 4).

Analyses of mutation-drift equilibria (Tajima, 1989; $\mathrm{Fu}, 1997)$ indicate that almost all sampled localities are in a genetic equilibrium (Table 5). Only for the Anavilhanas 
Archipelago, the Mamirauá Lake and the Tapará Community does Fu's $F$ s test show a significant genetic disequilibrium. However, when the Amazon basin is treated as one

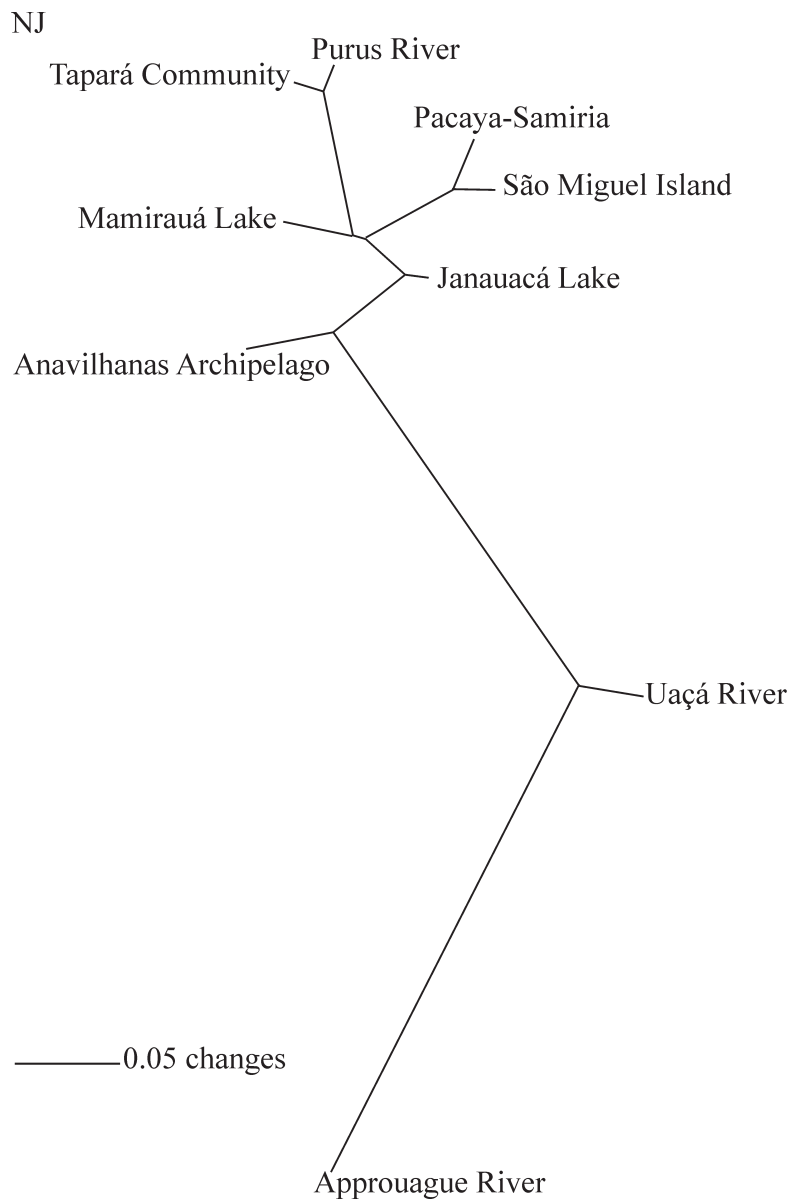

Figure 3 - Unrooted neighbor-joining $F_{S T}$ topology of C. crocodilus sampling localities. Branch lengths are proportional to genetic distances. large population, both statistics indicate a significant genetic disequilibrium (Tajima's $D=-2.548, \mathrm{p}<0.0001 ; \mathrm{Fu}$ 's $F s=-30.965, \mathrm{p}<0.0001)$.

\section{Discussion}

\section{Cytochrome $b$ polymorphism and genetic equilibria tests}

Gene diversity encountered in the present study was high $(\hat{\mathrm{H}}=0.733 ; 1085 \mathrm{bp})$, and comparable to the values $(\hat{\mathrm{H}}=0.692 ; 1142 \mathrm{bp})$ found in the study of Farias et al. (2004). These values are much higher than the value observed for Alligator mississippiensis $(\hat{\mathrm{H}}=0.153 ; 1317 \mathrm{bp})$ by Glenn et al. (2002). These values indicate that Caiman crocodilus populations retain high levels of genetic diversity in spite of historical events which reduced its population size. Neither the hypothesized climatic changes in the Amazon basin (Ab'Saber, 1977), nor recent commercial overexploitation (Smith, 1980; Da Silveira and Thorbjarnarson, 1999) appear to have affected the gene diversity of C. crocodilus populations. In contrast to C. crocodilus, the only other alligatorid crocodilian for which a comparable data set has been generated, the American alligator $A$. mississippiensis, shows much lower gene diversity (Glenn et al., 2002). This low gene diversity was attributed by the authors to severe reduction in population size during the Pleistocene, with a subsequent demographic expansion in the Holocene, but not to commercial overexploitation that also significantly reduced the census numbers of this species.

Of the nine localities studied, three (Table 5) show a significantly negative value for Fu's $F$ s test. Although this test was formally designed to test for selection, in the absence of selective advantage among haplotypes, a significant negative deviation from genetic equilibrium in

Table 4 - Matrix of pair-wise $F_{S T}$ values (below diagonal) and number of effective migrants $(\mathrm{Nm})$ between pairs of populations (above diagonal) separated by geographic distance (above diagonal in parentheses). * Significant values after Bonferroni correction $(\mathrm{p}<0.0014)$.

\begin{tabular}{|c|c|c|c|c|c|c|c|c|c|}
\hline Populations & $\begin{array}{l}\text { Purus } \\
\text { River }\end{array}$ & $\begin{array}{c}\text { Janauacá } \\
\text { Lake }\end{array}$ & $\begin{array}{l}\text { Anavilhanas } \\
\text { Archipelago }\end{array}$ & $\begin{array}{c}\text { Mamirauá } \\
\text { Lake }\end{array}$ & $\begin{array}{c}\text { Tapará } \\
\text { Community }\end{array}$ & $\begin{array}{l}\text { São Miguel } \\
\text { Island }\end{array}$ & $\begin{array}{l}\text { Uaçá } \\
\text { River }\end{array}$ & $\begin{array}{l}\text { Pacaya- } \\
\text { Samíria }\end{array}$ & $\begin{array}{c}\text { Approuague } \\
\text { River }\end{array}$ \\
\hline Purus River & - & $\begin{array}{c}5.3113 \\
(250 \mathrm{~km})\end{array}$ & $\begin{array}{c}2.4972 \\
(255 \mathrm{~km})\end{array}$ & $\begin{array}{c}20.3905 \\
(450 \mathrm{~km})\end{array}$ & $\begin{array}{c}\infty \\
(830 \mathrm{~km})\end{array}$ & $\begin{array}{c}13.0309 \\
(860 \mathrm{~km})\end{array}$ & $\begin{array}{c}0.9608 \\
(1720 \mathrm{~km})\end{array}$ & $\begin{array}{c}2.6401 \\
(1450 \mathrm{~km})\end{array}$ & $\begin{array}{c}0.1873 \\
(2050 \mathrm{~km})\end{array}$ \\
\hline $\begin{array}{l}\text { Janauacá } \\
\text { Lake }\end{array}$ & 0.0860 & - & $\begin{array}{c}4.0000 \\
(105 \mathrm{~km})\end{array}$ & $\begin{array}{c}16.2541 \\
(590 \mathrm{~km})\end{array}$ & $\begin{array}{c}4.3075 \\
(620 \mathrm{~km})\end{array}$ & $\begin{array}{c}6.7095 \\
(590 \mathrm{~km})\end{array}$ & $\begin{array}{c}1.6876 \\
(1700 \mathrm{~km})\end{array}$ & $\begin{array}{c}4.3917 \\
(1670 \mathrm{~km})\end{array}$ & $\begin{array}{c}0.4983 \\
(1750 \mathrm{~km})\end{array}$ \\
\hline $\begin{array}{l}\text { Anavilhanas } \\
\text { Archipelago }\end{array}$ & 0.1668 & 0.1111 & - & $\begin{array}{c}5.5869 \\
(605 \mathrm{~km})\end{array}$ & $\begin{array}{c}2.3885 \\
(715 \mathrm{~km})\end{array}$ & $\begin{array}{c}2.7013 \\
(645 \mathrm{~km})\end{array}$ & $\begin{array}{c}1.5888 \\
(1800 \mathrm{~km})\end{array}$ & $\begin{array}{c}2.2512 \\
(1655 \mathrm{~km})\end{array}$ & $\begin{array}{c}0.5211 \\
(1970 \mathrm{~km})\end{array}$ \\
\hline $\begin{array}{l}\text { Mamirauá } \\
\text { Lake }\end{array}$ & 0.0239 & 0.0298 & 0.0821 & - & $\begin{array}{c}9.4655 \\
(1250 \mathrm{~km})\end{array}$ & $\begin{array}{c}38.7575 \\
(1220 \mathrm{~km})\end{array}$ & $\begin{array}{c}1.9501 \\
(2290 \mathrm{~km})\end{array}$ & $\begin{array}{c}14.1938 \\
(1050 \mathrm{~km})\end{array}$ & $\begin{array}{c}0.6681 \\
(2450 \mathrm{~km})\end{array}$ \\
\hline $\begin{array}{l}\text { Tapará } \\
\text { Community }\end{array}$ & -0.0010 & 0.1040 & $0.1731 *$ & $0.0501 *$ & - & $\begin{array}{c}5.2000 \\
(30 \mathrm{~km})\end{array}$ & $\begin{array}{c}0.9052 \\
(1080 \mathrm{~km})\end{array}$ & $\begin{array}{c}1.8365 \\
(2300 \mathrm{~km})\end{array}$ & $\begin{array}{c}0.2019 \\
(1220 \mathrm{~km})\end{array}$ \\
\hline $\begin{array}{l}\text { São Miguel } \\
\text { Island }\end{array}$ & 0.0369 & 0.0693 & $0.1561 *$ & 0.0127 & 0.0877 & - & $\begin{array}{c}1.1213 \\
(1110 \mathrm{~km})\end{array}$ & $\begin{array}{c}1.2256 \\
(2330 \mathrm{~km})\end{array}$ & $\begin{array}{c}0.3608 \\
(1250 \mathrm{~km})\end{array}$ \\
\hline Uaçá River & $0.3422 *$ & $0.2285^{*}$ & $0.2393 *$ & $0.2040^{*}$ & $0.3558 *$ & $0.3083^{*}$ & - & $\begin{array}{c}1.2256 \\
(3340 \mathrm{~km})\end{array}$ & $\begin{array}{c}1.6788 \\
(170 \mathrm{~km})\end{array}$ \\
\hline $\begin{array}{l}\text { Approuague } \\
\text { River }\end{array}$ & $0.7274 *$ & $0.5008^{*}$ & $0.4896^{*}$ & $0.4280^{*}$ & $0.7122 *$ & $0.5808^{*}$ & 0.2294 & $0.5760 *$ & - \\
\hline
\end{tabular}


Table 5 - Indexes of genetic diversity and test of populational equilibria. $\mathrm{N}=$ number of individuals sampled, hp $=$ number of unique haplotypes observed, $\mathrm{S}=$ number of segregating (polymorphic) sites, $\theta=$ Watterson's Theta based on $\mathrm{S}, \pi=$ Nei's nucleotide diversity, $\hat{\mathrm{H}}=\mathrm{Nei}$ 's gene diversity. $*$ Significant values after Bonferroni correction $(\mathrm{p}<0.0056)$.

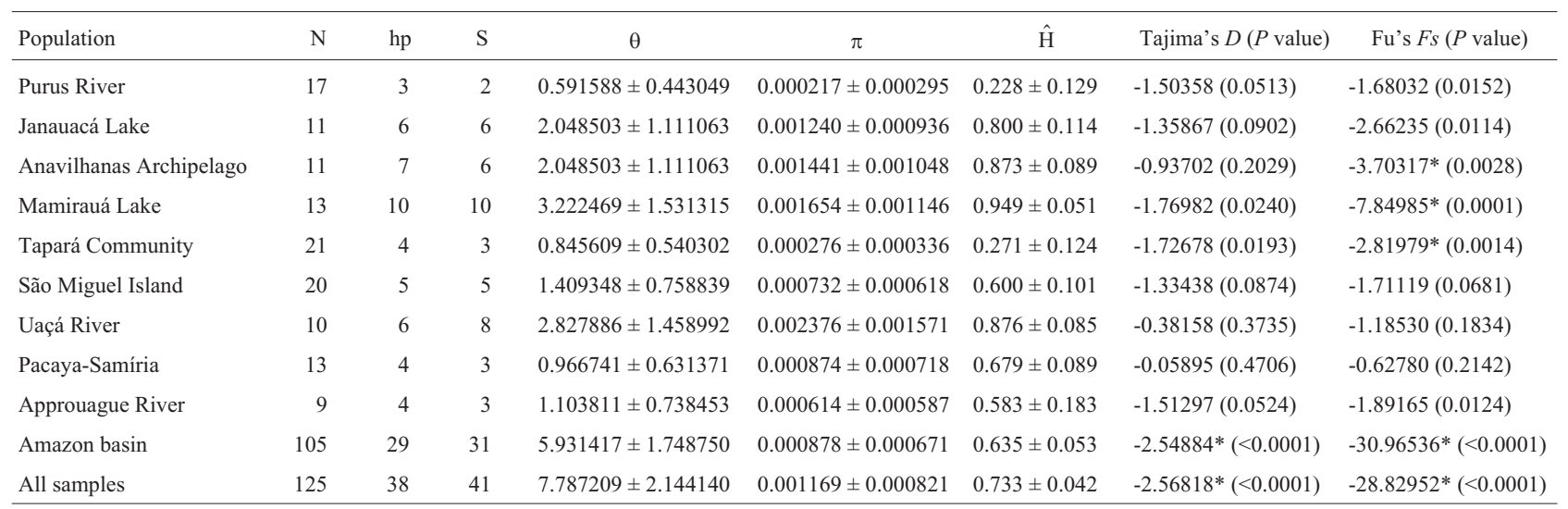

mtDNA alleles is most probably the result of recent population expansion (Rand, 1996; Hartl and Clark, 1997). Fu's Fs statistic is more sensitive to demographic events than is Tajima's $D$ (Rand, 1996). Thus, the inference drawn from our analyses suggests that while the Anavilhanas and Mamirauá localities - both of which are strictly protected at the federal and state level, respectively - and the Tapará locality have experienced a recent population expansion, this expansion was not very strong, and has been registered only by the most sensitive statistic. Some areas, however, show very little genetic evidence of population expansion, or of census number increase. These areas include the PacayaSamíria National Reserve (BM, pers. obs.) and the Uaçá Indigenous Area (Ruffeil, 2004) where C. crocodilus remains a popular food item, and is harvested in significant numbers. When all sampled localities are analyzed as one population, both Tajima's $D$ and Fu's Fs statistics are significantly negative. This result suggests an overall population expansion of this species that also has been registered as growth in census numbers (Rebêlo and Lugli, 2001). Again, the signal is not very strong and is only observed when the statistical power of the tests is increased by analyzing all samples together.

The genetic signal of overall population expansion is compatible with historical data and current observations. Caiman crocodilus is a habitat generalist. It also has been much less affected by the commercial trade than other sympatrically occurring species, such as Melanosuchus niger, Crocodilus intermedius or Crocodilus acutus, being harvested in large numbers only after these latter species became too severely depleted to support commercial operations. Because of the lack of ecological specialization (Herron, 1994), C. crocodilus was able to expand into habitats previously occupied by sympatrically occurring species (Da Silveira et al., 1997). Even when commercial hunters started harvesting the then plentiful C. crocodilus and precipitated its demographic decline, the present population is probably larger than were historical populations, which had to co-exist with large numbers of well established crocodilian species (Ross, 1998). Caiman crocodilus also has, once again, expanded following global and local harvest moratoria and regulations, experiencing two cycles of recent expansion, with an intervening period of decline, and it is this second expansion we are observing in the current pattern of genetic diversity.

\section{Inference of population genetic structure}

A minimum-spanning haplotype network was nested into higher level nesting categories (Templeton et al., 1992) and analyzed for non-random distribution of genetic diversity over geographic space (Templeton et al., 1995). The Nested Clade Analysis (NCA) allows identification of population genetic structure and the discrimination of various historical and ongoing processes responsible for the current pattern of genetic structuring. Its greatest power lies in that it requires no a priori hypothesis of population structure. Once patterns are observed, they can then be tested further.

Using the NCA approach we observed two hierarchical levels which have a significantly non-random distribution of genetic diversity. Inferences from level 3-1 suggest that the main populational dynamics responsible for the observed genetic differentiation of the Atlantic drainage systems not connected to the Amazon basin and Amazon basin localities are continuous range expansion, long distance colonization, or past fragmentation. However, past fragmentation is not very likely due to the small number of mutational steps separating the Uaçá and Approuague Rivers haplotypes from haplotypes found in the Amazon basin. When only the Amazon basin is analyzed, the inference at level 2-2 is continuous range expansion. Thus, continuous range expansion is likely to be the main dynamic within the Amazon basin, but due to insufficient sampling, we cannot differentiate between continuous range expansion or long distance colonization as the main populational dynamic responsible for the observed genetic differentia- 
tion between the Atlantic drainages not connected to the Amazon basin and Amazon basin sampling localities. Analysis of Molecular Variance (Excoffier et al., 1992), as well as pair-wise $F_{S T}$ values also support the inference that the Uaçá and Approuague Rivers are significantly differentiated from localities of the Amazon basin.

A possible factor that could have contributed to this distribution of genetic diversity is the present day distribution of river basins relative to their paleogeographic positions. The direction of the inferred colonization or range expansion is from the Amazon basin into the coastal drainages of French Guiana and Amapá State of Brazil. This could have occurred during the last Pleistocene glacial maximum when sea levels were up to $200 \mathrm{~m}$ lower than present. The Amazon delta extended much further east than its present position, and many of the now isolated coastal drainages were connected to the Amazon basin via the delta of the Amazon River. This would have facilitated dispersal and colonization of new areas, now outside the Amazon basin, during the glacial maximum. Modern alligators are less tolerant to salt water than other crocodilians since they posses neither a tongue gland in their mouth cavities that excretes salt, nor a reno-cloacal complex adapted for the excretion of salt and conservation of fresh water (Taplin and Grigg, 1989). For this reason, salt water is considered a major barrier to dispersal of Alligatoridae (Brochu, 2001), and it is unlikely they would have colonized the French Guiana and Amapá coastal drainages recently.

NCA analyses within the Amazon basin indicate that continuous range expansion is the most likely processes responsible for the observed distribution pattern of genetic diversity. Both AMOVA and Raymond and Rousset's test of exact population differentiation reject the hypothesis of panmixia; however, the distribution of genetic diversity is not compatible with the model of isolation-by-distance. In spatial autocorrelation analysis (Koenig, 1999; Diniz-Filho and Telles, 2002) which tests the hypothesis of isolationby-distance, geographic distances are partitioned into classes of connectivity or lack thereof at ever increasing distances. The spatial autocorrelolegram predicts elevated correlation at lower distances of connectivity with eventual leveling off, a pattern not observed in our data. The observed structure is therefore most likely the result of genetic subsampling of parental populations during periods of range expansion. However, range expansion did not proceed in a linear manner. Range expansion possibly proceeded locally as commercially more valuable species were being locally depleted by commercial hunters, and the resulting ecological space was being filled by an expanding C. crocodilus population. Alternatively, we may be observing a signature of coalescent processes in a species distributed over a large geographic area, thus a historical record rather than an ongoing process.

Another pattern which contributes to the rejection of panmixia within the Amazon basin is the significant differ- entiation of the Anavilhanas locality from all but the geographically closest Mamirauá Lake, Purus River and Janauacá Lake localities. The locality from the Anavilhanas archipelago is the only one sampled from a black water system (Sioli, 1984). Black water systems are limnologically and ecologically differentiated from white water systems, often supporting different animal and plant communities (Sioli, 1984; Goulding et al., 2003). There are a number of black water systems in the Amazon basin, but the Negro River is the largest. The observed differentiation of the Anavilhanas locality corroborates, in principle, the findings of Farias et al. (2004). Although Farias et al. (2004) did not include C. crocodilus from Anavilhanas in their analyses, they observed weak genetic differentiation between black water (Anavilhanas) and white water (rest of the Amazon basin) sampling localities of Melanosuchus niger, the other large alligatorid crocodilian found in Amazônia. Ecological differences between caiman populations occupying black water and white water habitats were also observed by Da Silveira (2002). Together, these genetic and ecological findings suggest that the observed black water / white water differentiation might be a real geographic structuring factor in Amazônia that reduces genetic exchange between limnologically differentiated systems. The two other significant pair-wise $F_{S T}$ comparisons observed within Amazônia occur between geographically distant localities.

The lack of pattern of genetic structuring among localities within the Amazon basin contrasts with the study of Verdade et al. (2002) who studied five geographically proximate populations of Caiman latirostris from the state of São Paulo. Based on an analysis of four microsatellite loci, Verdade et al. (2002) observed significant correlation between geographic and genetic distance. The habitat occupied by these populations is fragmented, which, combined with high mortality and low birth rates, should result in a low number of successfully dispersing individuals per generation leading to the pattern of isolation-by-distance (Verdade et al., 2002). The fragmented and discontinuous habitat occupied by $C$. latirostris contrasts with what is essentially a continuous habitat of the Amazon basin available to C. crocodilus. Nevertheless, the fragmented populations of $C$. latirostris outside the core continuous habitat of the Pantanal basin show a certain degree of differentiation, which is a classic pattern of peripatric differentiation observed in diverse taxa (Mayr 1963).

\section{Acknowledgments}

We would like to thank Sociedade Civil Mamirauá, The Mamirauá Institute, The Wildlife Conservation Society, The Nature Conservancy of Brazil and FAPEAM (Fundação de Amparo a Pesquisa no Estado do Amazonas) for financial support, RAN/IBAMA for permission to conduct field work, and CGEN/IBAMA for permission to conduct laboratory work. Renato Da Silveira, Pedro Alexandre Sampaio, Eduardo Matheus von Muhlen, Augusto Ruffeil 
and Marcelo Crossa helped in the field, and Richard Bodmer facilitated fieldwork in Peru, and the comments of two anonymous reviewers improved this publication.

\section{References}

Ab'Saber AN (1977) Espaços ocupados pela expansão des climas secos na América de Sul, po ocasião dos periodos glaçais quaternarios. Paleoclimas 3:1-18.

Bernatchez L (2001) The evolutionary history of brown trout (Salmo trutta L.) inferred from phylogeographic, nested clade, and mismatch analyses of mitochondrial DNA variation. Evolution 55:351-379.

Brisbin Jr. IL (1988) Growth curve analyses and their application to the conservation and captive management of crocodilians. In: King FW (ed) 9th Working Meeting of the Crocodile Specialist Group of the Species Survival Commission of IUCN - The World Conservation Union. IUCN, Gland, Switzerland, pp 116-145.

Brochu CA (2001) Congruence between physiology, phylogenetics, and the fossil record on crocodylian historical biogeography. In: Grigg G, Seebacher F and Franklin CE (eds) Crocodilian Biology and Evolution. Surrey Beatty and Sons, Sydney, Australia, pp 9-28.

Busack SD and Pandya S (2001) Geographic variation in Caiman crocodilus and Caiman yacare (Crocodylia, Alligatoridae): Systematics and legal implications. Herpetologica 57:294312.

Cantanhede AM, da Silva VMF, Farias IP, Hrbek T, Lazzarini SM and Alves-Gomes J (2005) Phylogeography and population genetics of the endangered Amazonian manatee, Trichechus inunguis Natterer, 1883 (Mammalia, Sirenia). Mol Ecol 14:401-413.

Castelloe J and Templeton AR (1994) Root probabilities for intraspecific gene trees under neutral coalescent theory. Mol Phylogenet Evol 3:102-113.

Clement M, Posada D and Crandall KA (2000) TCS: A computer program to estimate gene genealogies. Mol Ecol 9:16571659.

Cockerham CC and Weir BS (1993) Estimation of gene flow from F-statistics. Evolution 47:855-863.

Da Silveira R (2002) Conservação e manejo do jacaré-açu (Melanosuchus niger) na Amazônia Brasileira. In: Verdade LM and Larriera A (eds) Conservação e Manejo de Jadarés e Crocodilos da América Latina. V. 2, C.N. Editoria, Piracicaba, SP, pp 61-78.

Da Silveira R, Magnusson WE and Campos Z (1997) Monitoring the distribution, abundance and breeding areas of Caiman crocodilus crocodilus and Melanosuchus niger in the Anavilhanas Archipelago, Central Amazon, Brazil. J Herpetol 31:514-520.

Da Silveira R and Thorbjarnarson J (1999) Conservation implications of commercial hunting of Black and Spectacled Caiman in the Mamirauá sustainable development reserve, Brazil. Biol Conserv 88:103-109.

Diniz-Filho JAF and Telles MPDC (2002) Spatial autocorrelation analysis and the identification of operational units for conservation in continuous populations. Conserv Biol 16:924935.

Excoffier L, Smouse PE and Quattro JM (1992) Analysis of molecular variance inferred from metric distances among DNA haplotypes: Application to human mitochondrial DNA restriction data. Genetics 131:479-491.

Farias IP, Da Silveira R, de Thoisy B, Monjeló LA, Thorbjarnarson J and Hrbek T (2004) Genetic diversity and population structure of Amazonian crocodilians. Anim Conserv 7:265-272.

Fu Y-X (1997) Statistical tests of neutrality of mutations against population growth, hitchhiking and background selection. Genetics 147:915-925.

Glenn TC, Stanton JL, Lu A, Davis LM, Alvardo Bremer JR, Rhodes WE, Brisbin Jr. IL and Sawyer RH (2002) Low mitochondrial DNA variation among American alligators and a novel non-coding region in crocodilians. J Exp Zool (Mol Dev Evol) 294:312-324.

Goulding M, Barthem R and Ferreira EJG (2003) The Smithsonian Atlas of the Amazon. Smithsonian Institution Press, Washington, DC, $256 \mathrm{pp}$.

Hall T (1999) BioEdit: A user-friendly biological sequence alignment editor and analysis program for Windows 95/98/NT. Nucleic Acids Symp Ser 41:95-98.

Hartl DL and Clark AG (1997) Principles of Population Genetics. 3rd edition. Sinauer Associates, Sunderland, MA, 542 pp.

Herron JC (1994) Body size, spatial distribution, and microhabitat use in the caimans, Melanosuchus niger and Caiman crocodilus, in a Peruvian lake. J Herpetol 28:508-513.

Hrbek T, Farias IP, Crossa M, Sampaio I, Porto JIR and Meyer A (2005) Population genetic analysis of Arapaima gigas, one of the largest freshwater fishes of the Amazon basin: Implications for its conservation. Anim Conserv 8:297-308.

Janke A, Erpenbeck D, Nilsson M and Arnason U (2001) The mitochondrial genomes of the iguana (Iguana iguana) and the caiman (Caiman crocodylus): Implications for amniote phylogeny. Proc Roy Soc London B 268:623-631.

Koenig WD (1999) Spatial autocorrelation of ecological phenomena. Trends Ecol Evol 14:22-26.

Mantel N (1967) The detection of disease clustering and a generalized regression approach. Cancer Res 27:209-220.

Mayr E (1963) Animal Species and Evolution. Harvard University Press, Cambridge, MA, 811 pp.

Myers N, Mittermeier RA, Mittermeier CG, da Fonseca GAB and Kent J (2000) Biodiversity hotpots for conservation priorities. Nature 403:853-858.

Nei M (1987) Molecular Evolutionary Genetics. Columbia University Press, New York, NY, 512 pp.

Posada D, Crandall KA and Templeton AR (2000) GeoDis: A program for the cladistic nested analysis of the geographical distribution of genetic haplotypes. Mol Ecol 9:487-488.

Rand DM (1996) Neutrality tests of molecular markers and the connections between DNA polymorphism, demography, and conservation biology. Conserv Biol 10:665-671.

Raymond M and Rousset F (1995) An exact test for population differentiation. Evolution 49:1280-1283.

Rebêlo GH and Lugli L (2001) Distribution and abundance of four caiman species (Crocodylia, Alligatoridae) in Jaú National Park, Amazonas, Brazil. Rev Biol Trop 49:1095-1109.

Rice WR (1989) Analyzing tables of statistical tests. Evolution 43:223-225.

Ross JP (1998) Crocodiles. Status Survey and Conservation Action Plan. 2nd edition. IUCN - SSC, Crocodile Specialist Group, Gland, Switzerland, 167 pp. 
Rozas J, Sánchez-DelBarrio JC, Messenguer X and Rozas R (2003) DnaSP, DNA polymorphism analyses by the coalescent and other methods. Bioinformatics 19:2496-2497.

Ruffeil LAADS (2004) Abundância, reprodução, caça de subsistência e conservação de jacarés na terra indígena Uaçá, Amapá, Brasil. MSc Thesis, Museu Paraense Emílio Goeldi e Universidade Federal do Pará. Belém, Pará.

Sambrook J, Fritsch EF and Maniatis T (1989) Molecular Cloning: A Laboratory Manual. 2nd edition V. 1, Cold Springs Harbor Laboratory Press, Cold Springs Harbor, NY pp 1.21-1.29

Schneider S, Roessli D and Excoffier L (2000) Arlequin ver. 2000: A software for population genetic data analysis. Genetics and Biometry Laboratory, University of Geneva. Geneva, Switzerland.

Sioli H (1984) The Amazon and its main affluents: Hydrography, morphology of the river courses and river types. In: Sioli $\mathrm{H}$ (ed) The Amazon Limnology and Landscape Ecology of a Mighty Tropical River and its Basin. Dr. W. Junk Publishers, Dordrecht, The Netherlands, pp 127-165.

Smith NJH (1980) Caimans, capybaras, otters, manatees, and man in Amazônia. Biol Conserv 19:177-187.

Smith TB, Wayne RK, Girman DJ and Bruford MW (1997) A role for ecotones in generating rainforest biodiversity. Science 276:1855-1857.

Smith TB, Kark S, Schneider CJ, Wayne RK and Moritz C (2001) Biodiversity hotspots and beyond: The need for preserving environmental transitions. Trends Ecol Evol 16:431.

Staton MA and Dixon JR (1977) Studies on dry season biology of Caiman crocodilus from the Venezuelan Llanos. Mem Fund La Salle de Cienc Nat 35:237-265.

Swofford DL (2002) PAUP*. Phylogenetic Analysis Using Parsimony (* and Other Methods), Beta Version v4.10b. Sinauer Associates. Sunderland, MA.

Tajima F (1989) Statistical method for testing the neutral mutation hypothesis by DNA polymorphism. Genetics 123:585-595.

Taplin LE and Grigg GG (1989) Historical zoogeography of the eusuchian crocodylians: A physiological perspective. Amer Zool 29:885-901.
Templeton AR (1998) Nested clade analyses of phylogeographic data: Testing hypotheses about gene flow and population history. Mol Ecol 7:381-397.

Templeton AR (2001) Using phylogenetic analyses of gene trees to test species status and processes. Mol Ecol 10:779-791.

Templeton AR (2004) Statistical phylogeography: Methods of evaluating and minimizing inference errors. Mol Ecol 13:789-809.

Templeton AR and Sing CF (1993) A cladistic analysis of phenotypic associations with haplotypes inferred from restriction endonuclease mapping: IV. Nested analyses with cladogram uncertainty and recombination. Genetics 134:659-669.

Templeton AR, Boerwinkle E and Sing CF (1987) A cladistic analysis of phenotypic associations with haplotypes inferred from restriction endonuclease mapping. I. Basic theory and an analysis of alcohol dehydrogenase activity in Drosophila. Genetics 117:343-351.

Templeton AR, Crandall KA and Sing CF (1992) A cladistic analysis of phenotypic associations with haplotypes inferred from restriction endonuclease mapping and DNA sequence data: III. Cladogram estimation. Genetics 132:619-633.

Templeton AR, Routman EJ and Phillips CA (1995) Separating population structure from population history: A cladistic analysis of the geographical distribution of mitochondrial DNA haplotypes in the tiger salamander, Ambystoma tigrinum. Genetics 140:767-782.

Verdade LM, Zucoloto RB and Coutinho LL (2002) Microgeographic variation in Caiman latirostris. J Exp Zool (Mol Dev Evol) 294:387-396.

Watterson GA (1975) On the number of segregating sites in genetical models without recombination. Theor Pop Biol 7:256-276.

Weir BS and Cockerham CC (1984) Estimating F-statistics for the analysis of population structure. Evolution 38:1358-1370.

Zhang D-X and Hewitt GM (1996) Nuclear integrations: Challenges for mitochondrial DNA markers. Trends Ecol Evol $11: 247-251$

Associate Editor: Sérgio Furtado dos Reis 